\title{
DAMPAK KERUSAKAN LINGKUNGAN TERHADAP PEREMPUAN DAN ANAK
}

\author{
Oleh : \\ Andi Tenri Ampa, M.Si \\ BPKB Sulawesi Tenggara \\ Jl. Kijang no. 21 Kendari Sulawesi Tenggara
}

\begin{abstract}
Abstrak
Eksploitasi lingkungan hidup di Indonesia seolah telah menjadi tradisi pengelolaan Sumber Daya Alam (SDA) yang ada. Perubahan sistem pengelolaan SDA dari pusat menjadi otonomi daerah membawa dampak pada perubahan perilaku aktifitas masyarakat. Kepemilikan lahan yang bersifat common properties mulai dijadikan alasan individu untuk mengeksploitasi lahan secara bebas tanpa memperhatikan dampak kerusakan lingkungan, nilai ekonomi lahan jangka panjang, kondisi dan tata guna lahan yang benar.

Salah satu dampak yang paling rentan dan paling menderita dari eksploitasi SDA tersebut adalah perempuan dan Anak. Karena hubungan antara perempuan, anak-anak dan lingkungan hidup sangat jelas, dimana ketika terjadi eksploitasi terhadap lingkungan hidup maka dampak yang paling nyata adalah akan menimbulkan kemiskinan, daerah tertinggal dan traficking.
\end{abstract}

Kata kunci : eksploitasi, sumber daya alam, kemiskinan, traficking, 


\section{Pendahuluan}

Lingkungan adalah seluruh aspek hidup dan kehidupan di sekitar kita. Dunia sedang dihadapkan oleh berbagai macam istilah menyangkut kepentingan hidup manusia di atas bumi. Pada 1970, negara-negara maju telah memperkenalkan istilah sustain economics, yaitu upaya dan strategi pembangunan ekonomi yang fokus untuk mengejar laju pertumbuhan ekonomi negara. Namun, hasilnya tidak begitu memuaskan semua pihak termasuk juga modifikasi pembangunan ekonomi yang bertujuan memperbaiki nasib manusia tidak selalu berhasil dengan baik.

Apabila berbicara mengenai ketidakseimbangan dunia ekonomi dan sosial terhadap perempuan Indonesia di sinilah perempuan berperan. Lingkungan ekonomi atau fisik adalah lingkungan rumah dan halaman sekitarnya atau lingkungan tempat tinggal keluarga yang sekaligus tempat usaha atau lingkungan fisik keluarga. Sedangkan, lingkungan sosial adalah interaksi sosial antara anak dan orangtua, keluarga atau orang sekitarnya, serta hubungan antar keluarga dalam masyarakat.

Kondisi kesehatan lingkungan, dewasa ini, menunjukkan penurunan kualitas sejalan dengan situasi krisis ekonomi. Keadaan ini juga diperburuk oleh pelaku, yakni penduduk yang kurang peduli terhadap kesehatan lingkungan, tanpa menyadari "manfaat"yang diperoleh. Permasalahan kesehatan lingkungan di keluarga seperti perumahan, penyediaan air bersih, sampah, jamban, limbah, vektor, makanan, dan pencemaran udara, tanah, kebisingan, serta radiasi tidak bisa dilepaskan dari timbulnya penyakit berbasis lingkungan (PBL) terhadap perempuan.

Berbagai macam penyakit, seperti malaria, demam berdarah, diare, kecacingan, tuberkulosis paru, infeksi saluran pernapasan akut (ISPA), dan keracunan makanan adalah contoh dari penyakit berbasis lingkungan. Perilaku masyarakat dalam membuang sampah biasanya ikut menentukan terjadinya pencemaran lingkungan. 


\section{Lingkungan Sosial dan Perempuan}

Peranan suatu negara tidak terlepas dari dukungan perempuan, apakah sebagai ibu rumah tangga, pekerja profesional, dan lain sebagainya. Mereka bekerja melakukan aneka kegiatan. Mau tidak mau, perempuan turut serta melakukan segala macam upaya untuk memaksimalkan keuntungan atau laba yang dihasilkan pada waktu itu.

Dalam situasi waktu itu kaum perempuan secara langsung diharapkan mampu memaksimalkan pencapaian tujuan dan secara tidak langsung akan berdampak terhadap kepentingan negara. Kenyataannya, pertumbuhan ekonomi negara sedikit banyak meningkat saat itu yang hasilnya hanya dapat dinikmati oleh sebagian perempuan. Kenyataan selanjutnya, pada 1998, tidak sedikit perempuan dilanda oleh berbagai masalah dan akhirnya banyak perempuan tidak dapat melangsungkan aktivitasnya. Pada akhirnya, angka kematian ibu melahirkan terus meningkat (Samosir, J.T., 1980).

Saat ini, dunia telah memperkenalkan aneka istilah. Dunia telah mengalami pergeseran menyangkut pembangunan ekonomi dari sustain economics ke sustainable economic and sosial development for human development menjelang 2015. Dalam setiap pergeseran dengan munculnya istilahistilah baru, masyarakat khususnya kaum perempuan, akan terkena imbasnya. Di satu sisi, mereka lemah tidak memahami harus berbuat bagaimana dan seterusnya akan menghadapi apa dan harus melakukan tindakan bagaimana lagi menggapai 2015

Dewasa ini, jumlah penduduk Indonesia diperkirakan telah mencapai 222 juta orang, diantaranya 60 persen adalah perempuan. Pertumbuhan penduduk yang tinggi telah mendorong meningkatnya aktivitas masyarakat, baik dalam kerangka kegiatan sehari-hari untuk memenuhi kebutuhan hidup, maupun dalam kerangka pembangunan.

Kegiatan masyarakat mendorong munculnya permasalahan terhadap lingkungan, sehingga kerusakan dan pencemaran lingkungan terjadi di berbagai tempat. Penduduk perkotaan yang padat, dengan aktivitas tinggi telah menimbulkan berbagai pencemaran. Banyaknya kegiatan yang berpusat di 
perkotaan, seperti industri, jasa, dan perdagangan, telah menggeser struktur ekonomi yang semula dari pertanian menjadi ekonomi industri.

\section{Dampak Kerusakan Lingkungan Terhadap Perempuan}

Eksploitasi lingkungan hidup di Indonesia seolah telah menjadi tradisi pengelolaan Sumber Daya Alam (SDA) yang ada. Perubahan sistem pengelolaan SDA dari pusat menjadi otonomi daerah membawa dampak pada perubahan perilaku aktifitas masyarakat. Kepemilikan lahan yang bersifat common properties mulai dijadikan alasan individu untuk mengeksploitasi lahan secara bebas tanpa memperhatikan dampak kerusakan lingkungan, nilai ekonomi lahan jangka panjang, kondisi dan tata guna lahan yang benar.

Kebijakan terus digulirkan pemerintah sebagai upaya kepeduliannya terhadap derita lingkungan hidup. Akan tetapi kebijakan tersebut belum berpihak pada masyarakat. Hal ini disebabkan strategi pembangunan yang masih menjadikan Indonesia sebagai sumber bahan baku sebagai komoditi pertambangan, hutan, dan sebagainya. Bahkan konsep dasar pembangunan yang tidak berubah, yaitu orientasi ekonomi yang lebih besar. Selain itu penderitaan alam semakin parah setelah pemerintah mengeluarkan peraturan Pemerintah (PP) No. 2 tentang Penerimaan Negara Bukan Pajak (PNBP) yang berasal dari penggunaan kawasan hutan untuk pembangunan di luar kegiatan Kehutanan. PP ini justru memuluskan eksploitasi pertambangan. 11,4 juta hektar hutan lindung di Indonesia siap ditambang.

Akibat dari kesalahan kebijakan di atas terjadi degradasi, deforestastasi hutan dan lahan, serta kerusakan lingkungan lainnya mengakibatkan penurunan produktifitas alam dan kelestarian lingkungan. Begitupun dampak negatif akan penurunan ketahanan pangan utamanya untuk keluarga. Karena itu kondisi lingkungan ini perlu mendapat perhatian khusus.

Berbagai upaya nasional dan internasional telah dilakukan KNPP-PA untuk berkontribusi dalam memecahkan masalah lingkungan, khususnya yang terkait dengan upaya untuk mencegah timbulnya dampak negatif akibat perubahan iklim ini. Salah satu bentuk partisipasi KNPP \& PA antara lain melalui 
keikusertaan dalam konferensi PBB UNFCCC - COP 13 di Bali pada tahun 2007 yang lalu. KNPP-PA telah mendorong perempuan untuk menjadi motor penggerak dalam pengelolaan lingkungan untuk mencegah terjadinya perubahan iklim melalui penyelenggaraan side event “Gender and Climate Change”. Dalam event ini, para perempuan dunia ikut memberikan pemikiran apa yang dapat dilakukan dalam mengurangi atau mencegah meningkatnya suhu, sehingga pemanasan global dapat dikurangi dan dampak perubahan iklim dapat diatasi.

Perubahan iklim (climate change) saat ini telah menjadi salah satu ancaman global dan serius bagi keamanan manusia (human security). Berbagai efek dari perubahan iklim mempengaruhi seluruh lapisan masyarakat di berbagai belahan dunia. Perubahan iklim, sebagai suatu fenomena alam, muncul menjadi persoalan serius ketika cuaca bumi berubah sedemikian cepat seiring dengan meningkatnya intensitas aktivitas manusia.

Pertumbuhan populasi dunia yang mendorong peningkatan berbagai aktivitas konsumsi dan produksi energi untuk pembangunan ekonomi telah mempengaruhi kapasitas bumi untuk menyesuaikan dan memenuhi segala kebutuhan tersebut. Revolusi Industri di Eropa, misalnya, yang menyebabkan meningkatnya intensitas pembakaran kayu, batu bara, minyak dan gas, telah mengakibatkan peningkatan konsentrasi karbondioksida di atmosfir. Akibatnya permukaan bumi menjadi semakin panas dan temperatur meningkat tajam. Dalam laporan "State of World Population 2009" oleh United Nations Population Fund (UNFPA), perubahan iklim akibat berbagai aktivitas ekonomi tersebut akan menyebabkan temperatur bumi diperkirakan terus meningkat hingga 6.4 derajat pada tahun 2100 dari hanya sebesar 0.74 derajat di akhir tahun 1800an.

Pihak-pihak yang paling merasakan dampak perubahan iklim tersebut adalah negara-negara miskin dan kelompok masyarakat yang rentan, seperti perempuan dan anak-anak. Sebuah studi yang dilakukan oleh the London School of Economics and Political Science terhadap 141 negara yang terkena bencana pada periode 1981-2002 juga menemukan kaitan erat antara bencana alam dan status sosial ekonomi perempuan. 
Selain itu bencana alam ternyata berakibat pada penurunan angka harapan hidup perempuan dan peningkatan gender gap dalam masyarakat. Hal ini menunjukkan bahwa perempuan ternyata merupakan korban terbesar dari berbagai bencana alam yang terjadi. Akibatnya, terjadi peningkatan angka kemiskinan di kalangan perempuan dan semakin terbukanya jurang ketidaksetaraan gender karena perempuan harus menanggung beban tanggung jawab ganda yang lebih berat daripada laki-laki. Persoalannya, berbagai fakta empiris atas dampak perubahan iklim terhadap perempuan belum diiringi kesadaran akan pentingnya melibatkan perempuan, sebagai pihak yang "terlupakan", ke dalam berbagai pembahasan mengenai perubahan iklim.

Pengalaman yang berbeda antara laki-laki dan perempuan merupakan alasan penting mengingat perubahan iklim memiliki implikasi yang berbeda bagi laki-laki dan perempuan. Kondisi ironis tersebut kemudian mendorong munculnya berbagai inisiatif yang menekankan pentingnya mengintegrasikan perspektif perempuan dalam pengambilan kebijakan, diantaranya dengan cara melibatkan perempuan sebagai aktor dalam menyelesaikan persoalan terkait dengan perubahan iklim (Athiqah, 2010).

Perubahan iklim juga menjadi signifikan karena memiliki dampak kesehatan dan sosial bagi masyarakat luas. Berbagai bencana alam yang terjadi tidak hanya menyebabkan kematian, tapi juga meningkatkan potensi penyebaran berbagai penyakit bagi masyarakat sekitar. Diare, malaria, kolera adalah jenisjenis penyakit yang sering menghinggapi negara-negara yang terkena bencana alam akibat kenaikan air laut dan curah hujan. Hal ini dikarenakan dalam kondisi bencana, masyarakat sulit untuk memperoleh air bersih dan fasilitas sanitasi serta kesehatan yang memadai. Dampak kesehatan ini kemudian terkait erat dengan munculnya berbagai persoalan-persoalan sosial.

Menurut the Intergovernmental Panel on Climate Change (IPCC), dampak sosial tersebut dapat bervariasi tergantung pada faktor usia, kelas sosial ekonomi, pekerjaan dan gender. Dengan kata lain, perubahan iklim tidak hanya mengancam jiwa dan menyebabkan kematian, tapi juga memperluas disparitas antara kaum 
kaya dan miskin, menyebabkan perpindahan penduduk dan mempengaruhi pola relasi laki-laki dan perempuan yang menyebabkan ketidaksetaraan gender.

Perempuan sebagai kelompok masyarakat yang rentan, seringkali menjadi korban terbanyak dalam berbagai bencana besar, seperti tsunami Aceh, badai di Honduras dan Katrina di Amerika Serikat. Bagian selanjutnya dari tulisan ini akan secara khusus membahas implikasi perubahan iklim terhadap perempuan dan relasinya dengan laki-laki.

Perubahan iklim memiliki dampak sosial bagi relasi gender, terutama kondisi sosial ekonomi perempuan. Data-data menunjukkan tingginya jumlah perempuan yang menjadi korban dari berbagai fenomena alam akibat perubahan iklim. Bencana tsunami di Aceh, misalnya, sebanyak 55-70\% korban meninggal adalah perempuan. Bahkan di beberapa negara maju juga menunjukkan trend yang sama. Ketika terjadi bencana gelombang panas di Perancis pada tahun 2003 perempuan merupakan 70\% dari 15,000 korban meninggal. Selain itu, korban badai Katrina di Amerika Serikat (AS) adalah mayoritas perempuan miskin keturunan Amerika-Afrika, yang termasuk kategori masyarakat miskin di AS. Persoalannya, menurut laporan UNFPA, fakta akan tingginya angka kematian perempuan tidak disertai dengan berbagai kebijakan yang memberikan perhatian kepada perempuan dan anak sebagai pihak yang rentan terhadap bencana. Padahal bencana akibat perubahan iklim tersebut memiliki dua implikasi penting bagi perempuan.

Pertama, perubahan iklim yang menyulut bencana berimplikasi pada terciptanya kemiskinan di kalangan perempuan. Hal ini dapat dilihat terkait dengan pembagian kerja bagi perempuan yang berkontribusi terhadap terciptanya kemiskinan. Kebanyakan perempuan bekerja di sektor informal dan pertanian yang rentan secara ekonomi terhadap bencana alam. Keduanya tergolong sektor dengan tingkat kerusakan terparah ketika terjadi suatu bencana alam. Akibat bencana, para perempuan yang menggantungkan hidupnya di sektor tersebut menderita kerugian yang luar biasa karena kehilangan pekerjaan dan jatuh miskin.

Kondisi ini kemungkinan berbeda bagi perempuan yang masih memiliki dan tinggal bersama suami dengan perempuan yang menjadi orangtua tunggal, 
baik masih bersuami maupun sudah berstatus janda. Jika kondisi tersebut terjadi, perempuan bersuami masih dapat bertahan hidup dengan mengandalkan pemasukan dari suami yang mungkin bekerja di sektor lain atau mereka masih dapat menegosiasikan alternatif pekerjaan lain yang bisa dilakukan. Namun dalam kasus ini, terkadang perempuan mengalami persoalan dalam hal bargaining power dalam menentukan kebijakan. Rendahnya kekuatan perempuan untuk mengambil keputusan masih menjadi penghalang bagi perempuan untuk merealisasikan berbagai inisiatif ekonomi untuk meningkatkan sumber pendapatan alternatif bagi keluarganya.

Sementara itu, implikasi bencana alam bagi perempuan yang menjadi orangtua tunggal tidaklah lebih baik. Meskipun mereka cenderung lebih bebas dalam membuat keputusan, kondisi sosial ekonomi perempuan tidak akan serta merta menjadi lebih baik. Bencana alam yang menyebabkan hilangnya sumber mata pencahariaan semakin memperparah kondisi ekonomi mereka. Banyak perempuan di Bangladesh, misalnya, telah menjadi orangtua tunggal sekian lama dan berjuang memenuhi kebutuhan keluarganya di tengah potensi ancaman bencana banjir yang kerap terjadi. Para perempuan tersebut menjadi kepala keluarga karena suami-suami mereka bermigrasi ke negara lain untuk bekerja.

Selain dalam hal pembagian kerja, kemiskinan akibat perubahan iklim juga terjadi di kalangan perempuan karena mereka tidak atau hanya sedikit memiliki aset ekonomi, seperti lahan. Data dari Institute for Social and Environmental Transition menguak bahwa ternyata secara global hanya kurang dari $2 \%$ perempuan dunia yang memiliki lahan. Padahal aset-aset tersebut dapat dijual sehingga bermanfaat untuk menopang hidupnya dan membantu memulihkan kondisinya pascabencana. Akibatnya, ketika perempuan tidak memiliki kekuatan ekonomi dalam keluarga maka perempuan tidak memiliki banyak peluang untuk memperbaiki kondisi ekonominya, termasuk dalam situasi darurat seperti bencana alam.

Implikasi kedua perubahan iklim terhadap perempuan yaitu memperparah ketidaksetaraan dalam relasi gender antara laki-laki dan perempuan. Argumen ini berangkat dari asumsi bahwa ketidaksetaraan gender tersebut sebenarnya telah ada 
di masyarakat sebelum bencana alam terjadi. Lalu ketidaksetaraan menjadi kian nyata ketika bencana tersebut datang sehingga menyebabkan perempuan sebagai mayoritas korban dalam suatu bencana alam. Ketidaksetaraan gender dalam konteks ini terkait erat dengan perbedaan kemampuan perempuan dan laki-laki dalam mengakses sumber daya, informasi, mobilitas dan proses pembuatan kebijakan sehingga menentukan siapa yang paling merasakan dampak dari bencana alam. Ketidaksetaraan gender dalam hal terbatasnya akses perempuan terhadap bencana dapat terlihat mulai dari kesiapan menghadapi bencana (disaster preparedness), pencegahan hingga rehabilitasi.

Dalam beberapa kasus, ketidaksetaraan gender terlihat ketika perempuan tidak mendapat peringatan sebelum bencana alam terjadi sehingga mereka tidak sempat meninggalkan rumahnya untuk menyelamatkan diri. Akibatnya perempuan lebih banyak menjadi korban daripada laki-laki dalam bencana alam. Sementara itu, ketika bencana alam telah terjadi, ketidaksetaraan gender semakin mengemuka dari semakin menguatnya peran-peran tradisional perempuan. Perempuan di banyak negara berkembang bertanggung jawab dalam peran untuk memenuhi kebutuhan keluarga, termasuk air bersih dan makanan. Namun bencana alam, yang bukan merupakan situasi normal, semakin mempersulit akses perempuan terhadap berbagai sumber daya, seperti air, sanitasi dan energi untuk memasak.

Perempuan harus berkompetisi dengan laki-laki untuk mengamankan sumber daya guna kelangsungan hidup. Bahkan seorang ilmuan menyatakan situasi ini sebagai pilihan hidup atau mati bagi perempuan. Padahal akses perempuan terhadap sumber daya ini penting karena terkait erat dengan memenuhi kebutuhan hidup keluarganya dan bukan hanya untuk kebutuhannya secara pribadi. Situasi bencana alam ini akhirnya menciptakan beban ganda bagi perempuan. Perempuan tidak hanya bertanggungjawab untuk memastikan terpenuhinya kebutuhan reproduksi keluarga, tapi juga harus berjuang untuk mendapatkannya. Karena besarnya kedua tanggung jawab ini, perempuan tidak lagi memperhatikan kesehatan reproduksi dan seksual mereka sehingga kesehatannya terancam. 
Situasi pasca bencana yang telah memasuki masa rehabilitasi, seringkali justru memperparah ketidaksetaraan gender. Pada masa ini, para perempuan muda masih sibuk berkutat pada pemenuhan tanggung jawab tersebut. Mereka enggan untuk kembali ke bangku sekolah guna mengenyam pendidikan dan lebih memilih bermigrasi menjadi buruh untuk memenuhi kebutuhan hidup keluarganya. Bahkan ketidaksetaraan gender terjadi dalam hal meningkatnya kekerasan seksual dan kekerasan dalam rumah tangga. Pengalaman di Malawi, misalnya, menunjukkan bahwa meningkatnya angka perceraian di kalangan perempuan muda mewarnai kondisi masyarakat pascabencana. Perceraian kemudian menggiring para perempuan tersebut terjun ke dunia prostitusi guna bertahan hidup dan mendorong pada meluasnya penyebaran virus HIV/AIDS di negara tersebut.

Pembahasan di atas menunjukkan bahwa perubahan iklim yang menyebabkan bencana alam telah menjadi sumber permasalahan yang berdampak sosial bagi perempuan dan menghambat proses pembangunan pascabencana. Padahal keterlibatan perempuan sebagai bagian dari masyarakat sangat diperlukan dalam pembangunan negara. Oleh karena itu, paradigma pembangunan di banyak negara tidak lagi menempatkan perempuan sebagai objek yang terkena dampak dari perubahan iklim. Perempuan juga dapat menjadi subjek atau aktor yang berperan untuk mencegah dan mengatasi dampak sosial ekonomi dan berkontribusi dalam pembangunan. Bagian selanjutnya akan membahas lebih detil peran-peran yang telah dilakukan perempuan dalam mengatasi efek perubahan iklim. 


\section{Daftar Rujukan}

Anonemous. 2008. Gerakan Perempuan Lamongan dalam Penyelamatan Hutan. Profil Kabupaten Lamongan.

Anonemous. 2008. Model Pemberdayaan Perempuan dalam Pengelolaan Lingkungan Hidup. Kementerian Negara Pemberdayaan Perempuan dan Perlindungan Anak (KNPP-PA). Tanggal akses 20 januari 2010.

Athiqah, N.A. 2010. Perempuan dan Dampak Perubahan Iklim. Suara Pembaharuan. Terbit pada tanggal 22 Januari 2010.

Azizah, N. Eratkah Perempuan dengan Lingkungan ?. Jurnal Perempuan.comJakarta. Tanggal akses 20 Januari 2010

Samosir, J.T. 2009. Peran Perempuan dalam Mitigasi dan Adaptasi. Makalah Pada Acara Launching "State Of World Population Report 2009. 